\title{
Communication
}

[Comunicação]

\section{Antimicrobial susceptibility of coagulase-negative staphylococci isolated from meat- producing ewes with mastitis}

\author{
[Susceptibilidade antimicrobiana de cepas de estafilococcos coagulase-negativa isolados de \\ ovinos de corte com mastite] \\ A.M.M.P. Della Libera, M.G. Blagitz, F.N. Souza, C.F. Batista, M.R. Azedo \\ N.R. Benites, P.A. Melville, V. Gomes \\ Faculdade de Medicina Veterinária e Zootecnia - USP \\ Av. Prof. Dr. Orlando Marques de Paiva, 87 \\ 05508-270 - São Paulo, SP
}

\begin{abstract}
Mastitis is an important disease of sheep with serious economic losses, even in meat-producing sheep (Moroni et al., 2007). Coagulase-negative staphylococci (CNS) are the main cause of mastitis in small ruminants (Bergonier and Crémoux, 2003).
\end{abstract}

Antimicrobial therapy is an important tool in scheme of mastitis control, and the misuse or intensive use of antimicrobials can lead to the development of resistance among different bacterial strains and contamination of foodstuff, with animal and human implications (Costa et al., 2000; Constable and Morin, 2003). Indeed, CNS infections and antimicrobial resistance have been growing concern worldwide, even in humans. Sometimes, the importance of CNS is negligible. Therefore, these bacteria obtained from dairy products were involved in many outbreaks of food poising in Brazil and it has been showed their ability to produce active toxin (Veras et al., 2008). Furthermore, CNS can function as a reservoir for antimicrobial resistance genes and virulence factors to Staphylococcus aureus (Archer and Climo, 1994).

Studies have determined the antibacterial susceptibility patterns for cattle, goats, and dairy sheep, in which the use of antimicrobials are more common. Therefore, much less information is available for meat-producing sheep.
The purpose of this in vitro study was to determine the susceptibility of CNS isolates from cases of mastitis in meat-producing ewes for several antimicrobial agents.

Antimicrobial susceptibility test was carried out on 121 CNS isolates from field cases of mastitis in Santa Ines ewes from 17 flocks located in the São Paulo State, Brazil. Milk samples (10mL) were aseptically collected, and the presence of bacteria was determined by culturing $0.01 \mathrm{~mL}$ of each sample on $5 \%$ ovine blood agar incubated for $24-48$ hours at $37^{\circ} \mathrm{C}$.

The microbial strains were presumptively identified on the basis of morphology and Gram staining of the colonies. Then, Gram positive cocci were tested for catalase and coagulase production. Afterwards, the CNS species were identified by biochemical tests as described by Krieg and Holt (1994).

Drugs susceptibility testing was performed by agar disk diffusion method. Briefly, five colonies of each CNS isolates from brain and heart infusion agar were suspended in $2 \mathrm{~mL}$ sterile saline to a density approximately equal to MacFarland opacity density No. 0.5-1.0. The bacterial suspension was inoculated onto Mueller-Hilton agar. Then, the discs containing penicillin (10 $\mathrm{g})$, ampicillin $(10 \mu \mathrm{g})$, amoxicillin $(30 \mu g)$, gentamicin $(10 \mu g)$, neomycin $(30 \mu g)$,

Recebido em 16 de abril de 2010

Aceito em 10 de dezembro de 2010

E-mail: dellalibera@usp.br 
tetracycline $(30 \mu \mathrm{g}), \quad$ sulfonamide $(300 \mu \mathrm{g})$, streptomycin $(10 \mu \mathrm{g})$, cefalotin $(30 \mu \mathrm{g})$, and oxaciclin $(1 \mu \mathrm{g})$ (Cefar - São Paulo, Brazil) were applied. Isolates were categorized as susceptible, intermediate, and resistant by measurement of the inhibition zone diameter as given by National Committee of Clinical Laboratory Standards (National..., 1999). Oxaciclin was included for detection of methicillin resistance (MR) because it is more stable than methicillin and provide more reliable results (National..., 1999).

From the total 560 milk samples collected, 130 (23.2\%) were positive in bacteriological culture. Surveys in various sheep populations have demonstrated high prevalences of intramammary infections as encountered here ranging from $12 \%$ to up to $40 \%$ (Moroni et al., 2007). In the present study, CNS were the most frequent pathogens isolated (93.1\%), that was similar to other authors (Bergonier and Crémoux, 2003).

All isolates were sensible to at least one antimicrobial agent. The in vitro activities of each of the antimicrobial agents tested against CNS are summarized in Table 1 . The highest antimicrobial resistance was observed against sulphonamide (27.3\%), followed by streptomycin (14.5\%), and oxaciclin (14.0\%).

Table 1. In vitro antimicrobial susceptibility test of 121 coagulase-negative staphylococci strains, isolated from 560 milk samples obtained from Santa Inês ewes with mastitis in São Paulo, Brazil

\begin{tabular}{lccc}
\multicolumn{1}{c}{$\begin{array}{c}\text { Antimicrobial } \\
\text { agent }\end{array}$} & $\begin{array}{c}\text { Susceptible } \\
\%\end{array}$ & $\begin{array}{c}\text { Intermediate } \\
\%\end{array}$ & $\begin{array}{c}\text { Resistant } \\
\%\end{array}$ \\
\hline Penicillin & 88.43 & 0.00 & 11.57 \\
Ampicillin & 89.26 & 0.00 & 10.74 \\
Amoxicillin & 89.26 & 0.00 & 10.74 \\
Gentamicin & 98.35 & 0.00 & 01.65 \\
Neomycin & 92.56 & 1.65 & 05.79 \\
Tetracycline & 89.18 & 1.65 & 09.17 \\
Sulfonamide & 72.73 & 0.00 & 27.27 \\
Streptomycin & 85.12 & 0.83 & 14.05 \\
Cefalotin & 95.04 & 1.65 & 03.31 \\
Oxaciclin & 85.95 & 0.00 & 14.05 \\
\hline
\end{tabular}

Based on many available reports, the results related to susceptibility of CNS isolated from mastitis in ruminants cases to antimicrobial agents are very inconsistent (Fthenakis, 1998; Costa et al., 2000; Machado et al., 2008; Pyörälä and Taponen, 2009). For example, gentamicin, a bactericidal agent, was described to be the most in vitro active against susceptible CNS in humans (Archer and Climo, 1994) and in dairy cows (Gentilini et al., 2002) as observed here. Hence, it has also been reported that some isolates can carry genes encoding an enzyme mediating resistance to some aminoglicosids but the same was not true for gentamicin (Archer and Climo, 1994). Although, some reports present gentamicin as one of the most in vitro resistant antimicrobial agent in dairy ewes (Fthenakis, 1998) and dairy cows (Machado et al., 2008). Therefore, it has to be emphasized that the antimicrobial susceptibility pattern can vary among regions and by management practices.
In the present study, $82.3 \%, 35.3 \%, 52.9 \%$, $11.8 \%$, and $88.2 \%$ of methicillin-resistant isolates, given by oxaciclin resistance, were also resistance to sulfonamide, tetracycline, neomycin, gentamicin, and streptomycin, respectively. These results were much higher compared to $18.3 \%, 8.6 \%, 0.0 \%, 0.0 \%$, and $2.9 \%$ of methicillin-susceptible isolates that were resistant to the same antimicrobial agents, correspondingly. This fact can explain the considerable multidrug resistance $(20.7 \%)$ found here that point out to a problem of increase resistance among staphylococcal isolates. It has also been described the most important mechanism for resistance of staphylococci species to beta-lactams is production of a lowaffinity penicillin-binding protein, PBP2a. This resistance, designated methicillin-resistance or oxaciclin resistance, effectively precludes therapy with any of available beta-lactam antimicrobial agent. The gene encoding PBP2a, $m e c A$, is identical among all staphylococci. Indeed, it is well-known that methicillin 
resistance also predicts resistance to multiple classes of antimicrobial agents besides betalactams (Archer and Climo, 1994). Thus, the methicillin-resistance could be used as an indicator of the presence of pathogenicity islands that contain virulence factors other than penicillin resistance itself that might contribute to the ability of bacteria to survive antimicrobial treatment. Recently, the multidrug resistance was commonly found in CNS isolates from mastitis in dairy cows in Brazil (Machado et al., 2008). In fact, Gentilini et al. (2002) recommended that animals that carry methicillin-resistant CNS isolates should be culled.
On the other hand, regarding antimicrobial susceptibility testing method, none of the approved standards for veterinary pathogens have been validated for mastitis pathogens and its relevance to mastitis outcome is still under discussion (Constable and Morin, 2003). Finally, in the present study, the susceptibility patterns among CNS species was not evaluated. Further studies would be valuable to identify the potential differences between CNS species since they are related to mammary pathogenicity, and antimicrobial and clinical outcomes.

Keywords: ewe, mastites, coagulase-negative staphylococci

\section{RESUMO}

Avaliou-se a sensibilidade antimicrobiana in vitro de 121 cepas de estafilococos coagulase-negativa isolada de leite de ovelhas Santa Inês, aos fármacos: penicilina, amoxicilina, ampicilina, estreptomicina, oxaciclina, neomicina, cefalotina, gentamicina e sulfonamida. A resistência à sulfonamida foi a mais frequente $(27,3 \%)$, seguida pela estreptomicina (14,0\%) e pela oxaciclina (14,0\%), enquanto da gentamicina $(1,6 \%)$ foi a menos frequente. Todas as cepas foram sensíveis a pelo menos um antimicrobiano, e 20,3\% das cepas apresentaram resistência múltipla. Os resultados mostram a importância de Staphylococci coagulase-negativas como agentes causadores de mastite em ovinos, e o perfil de resistência múltipla indica a importância da determinação da resistência à oxaciclina como indicador da presença de ilhas de patogenicidade que contêm fatores de virulência e resistência a outros antimicrobianos que contribuem para a sobrevivência da bactéria ao tratamento.

Palavras-chave: ovelha, mastite, estafilococos coagulase-negativa

\section{ACKNOWLEDGEMENTS}

The authors are grateful to the Fundação de Amparo à Pesquisa do Estado de São Paulo by financial support.

\section{REFERENCES}

\author{
ARCHER, G.L.; CLIMO, M.W. Antimicrobial \\ susceptibility of coagulase-negative \\ staphylococci. Antimicrob. Agents Chemother., \\ v.38, p.2231-2237, 1994.
}

BERGONIER, D.; CREMOUX, R.; RUPP, R. et al. Mastitis in small dairy ruminants. Vet. Res., v.34, p.689-716, 2003.

CONSTABLE, P.D.; MORIN, D.E. Treatment of clinical mastitis. Using antimicrobial susceptibility profiles for treatment decisions. Vet. Clin. N. Am.: Food Anim. Pract., v.19, p.109-138, 2003.
COSTA, E.O.; BENITES, N.R.; GUERRA, J.L. et al. Antimicrobial susceptibility of Staphylococcus spp. isolated from mammary parenchymas slaughtered dairy cows. J. Vet. Med. B., v.47, p.99-103, 2000.

FTHENAKIS, G.G. Susceptibility to antibiotics of staphylococcal isolates from cases of ovine and bovine mastitis in Greece. Small Ruminant Res., v.28, p.9-13, 1998.

GENTILINI, E.; DENAMIEL, G.; BETANCOR, A. et al. Antimicrobial susceptibility of coagulase-negative staphylococci isolated from bovine mastitis in Argentina. J. Dairy Sci., v.85, p.1913-1917, 2002.

KRIEG, N.R.; HOLT, J.C. Bergey's Manual of Systematic Bacteriology. 9.ed. Baltimore: Williams \& Wilkins, 1994. 1368p.

MACHADO, T.R.O.; CORREA, M.G.; MARIN, J.M. Antimicrobial susceptibility of coagulasenegative Staphylococci isolated from mastitic cattle in Brazil. Arq. Bras. Med. Vet. Zootec., v.60, p.278-282, 2008. 
MORONI, P.; PISONI, G.; VARISCO, G. et al. Effect of intrammary infection in Bergamasca meat sheep on milk parameters and lamb growth. J. Dairy Res., v.74, p.34-344, 2007.

NATIONAL Committee of Clinical Laboratory Standards: performance standards for antimicrobial disk and dilution susceptibility test for bacteria isolated from animals. Approved Stand. 19 (11), 67, 1999. Wayne, PA: NCCLS, 1999.
PYÖRÄLÄ, S.; TAPONEN, S. Coagulasenegative staphylococci- Emerging mastitis pathogens. Vet. Microbiol., v.134, p.3-8, 2009.

VERAS, J.F.; CARMO, L.S.; TONG, L.C. et al. A study of the enterotoxigenicity of coagulasenegative and coagulase-positive staphylococcal isolates from food poising outbreaks in Minas Gerais, Brazil. Int. J. Infect. Dis., v.12, p.410415, 2008. 